\title{
EFFECTS OF LYSINE SUPPLEMENTATION ON PERFORMANCE CHARACTERISTICS AND MINERAL RETENTION OF BROILER CHICKENS FED RAW BENNE SEED BASED DIETS
}

\author{
A. M. Akanji and O.E. Fasina \\ Department of Animal Production, College of Agricultural Sciences, \\ Olabisi Onabanjo University, Ayetoro Campus, Ogun State - Nigeria \\ CorrespondingE-mail: adetayo883@gmail.com
}

Received March 20, 2016; Accepted April 04, 2016

\begin{abstract}
ABSTRAK
Tujuan penelitian untuk menentukan pengaruh biji benne mentah atau RBS (Sesamum indicum) dengan atau tanpa suplementasi lisin terhadap karakteristik penampilan dan retensi mineral pada ayam broiler. Rancangan acak lengkap digunakan pada penelitian ini dengan tujuh perlakuan dan 20 ulangan per per perlakuan. Pemberian pakan dilakukan selama 56 hari. Anak ayam umur 140 hari (strain Marshall) tanpa dibedakan jenis kelamin digunakan sebagai materi penelitian. RBS dimasukkan ke dalam pakan pada tingkat $15 \%$ dan $30 \%$ dan ditambah dengan lisin masing-masing sebanyak $0 \% ; 0,25 \%$ dan $0,5 \%$. Hasil penelitian menunjukkan bahwa rataan konsumsi pakan mingguan pada ayam yang diberi pakan kontrol dan pakan basal 15\% RBS yang ditambah $0,25 \%$ dan $0,5 \%$ lisin tidak menunjukkan perbedaan nyata, tetapi lebih tinggi $(\mathrm{P}<0.05)$ dibanding dengan yang diberi pakan lainnya. Efisiensi konversi pakan dan rasio efisiensi protein secara nyata $(\mathrm{P}<0,05)$ menurun pada ayam yang diberi pakan $30 \%$ RBS dengan atau tanpa penambahan lisin. Pakan dengan penambahan lisin $0,25 \%$ dan $0,5 \%$ meningkatkan $(\mathrm{P}<0,05)$ retensi nitrogen, kalsium, fosfor dan zat besi pada ayam yang diberi pakan berbasis $15 \%$ RBS, tapi menurun $(\mathrm{P}<0,05)$ pada ayam yang diberi pakan $30 \%$ RBS. Penurunan karakteristik penampilan ayam yang diberi pakan 30\% RBS dengan atau tanpa lisin dapat dikaitkan dengan interaksi efek racun dari faktor-faktor antinutritional yang lebih tinggi seperti tannin, oksalat dan fitat. Kesimpulannya, indeks respon meningkat ketika 15\% RBS ditambah 0,5\% lisin kepada ayam.
\end{abstract}

Kata kunci: biji benne, penambahan lysine, penggunaan

\begin{abstract}
The objective of the study was to determine the effects of raw benne seed (RBS, Sesamum indicum) with or without lysine supplementation on the performance characteristics and mineral retention of broiler chickens. The feeding trial lasted for 56 days. One hundred and forty unsexed day old broiler chicks (Marshall strain) were used for the study. RBS was incorporated into the diets at 15\% and $30 \%$ levels and supplemented with $0 \%, 0.25 \%$ and $0.5 \%$ of lysine, respectively. Average weekly feed intake in birds fed the control diet and 15\% RBS based diet supplemented with $0.25 \%$ and $0.5 \%$ lysine were not significantly different, but significantly $(\mathrm{P}<0.05)$ higher than those fed other diets. Feed conversion efficiency and protein efficiency ratio were significantly $(\mathrm{P}<0.05)$ reduced in birds fed $30 \%$ RBS with or without lysine supplementation. At $0.25 \%$ and $0.5 \%$ lysine supplementation, significant $(\mathrm{P}<0.05)$ increases were obtained in the retention of nitrogen, calcium, phosphorus and iron in birds fed $15 \%$ RBS based diets, but markedly reduced in those fed 30\% RBS based diets. The reductions in the performance characteristics of the birds fed 30\% RBS diets with or without lysine can be attributed to interactions in the toxic effects of the higher intakes anti-nutritional factors like tannin, oxalate and
\end{abstract}


phytate. In conclusion, the response indices were better enhanced when 15\% RBS supplemented with $0.5 \%$ lysine was fed to the birds.

Keywords: benne seeds, lysine supplementation, utilization

\section{INTRODUCTION}

Benne seed (Sesamum indicum) is an oil seed but with low cholesterol level. It has a crude protein content as high as $40 \%$ especially when defatted. The protein is rich in arginine, leucine and methionine, but rather deficient in lysine (Lutz and Pryztulski, 2008). As a result of the low content of lysine in benne seed, Mamputu and Buhr (1991) stated that it could not be used as the major protein supplement in broiler rations. Akanji.(2002) reported that for effective utilization of benne seed, there must be a sufficient supplementation with lysine.

Apart from lysine deficiency, raw benne seeds like some grain legumes contain some antinutritional factors which are capable to cause impairment of growth of birds (Emiola et al., 2003). The hulls of benne seeds have been reported to high amounts of tannin, phytate and oxalate which form complexes with dietary protein and divalent minerals (Permaul, 2009). According to Maga (1982), the main nutritional concern associated with phytate lies in its interaction with several minerals and proteins. It binds up certain metal ions, such as calcium, magnesium, zinc, copper and iron to form insoluble phytate metal complexes that are not readily broken down, thus rendering them unavailable or only partially available for absorption in the intestinal tract of an animal.

Blood and Henderson (1974) stated that excess oxalate ingestion causes some gastrointestinal irritation, renal damage, precipitation of blood calcium and production of a hypocalcaemc syndrome of muscular weakness and paralysis. Tannins when ingested in high amounts have been reported to exert adverse effects on growth or egg production (Akanji, 2002). However, according to Apata (1990), there is a level of ingestion of the anti- nutritional factors beyond which adverse effects will be noticed in the body of non-ruminant animals. Therefore, as a result of the deficiency in lysine content coupled with the inherent anti-nutritional factors, this study was designed to look at the effects of raw benne seeds at $15 \%$ and $30 \%$ levels of incorporation in the diets with or without lysine supplementation on performance characteristics and mineral retention of broiler chickens.

The objective of this study was to determine the effects of raw benne seed (RBS) with or without lysine supplementation on the performance characteristics and mineral retention of broiler chickens

\section{MATERIALS AND METHODS}

Raw benne seeds sourced from open market in Ibadan, South Western Nigeria, were air-dried and incorporated into broiler diets with or without lysine supplementation.

\section{Experimental Diets}

Seven experimental diets (Tables 1 and 2) were formulated in a completely randomized design in which RBS were incorporated into the broiler starter and finisher diets at 15\% and 30\% levels. Synthetic lysine was also incorporated into the diets at $0 \%, 0.25 \%$ and $0.5 \%$ levels.

\section{Birds and Management}

A total of 140 day-old unsexed broiler chicks of Marshall strain were divided into seven groups at 20 birds per group. Each group was replicated four times at 5 birds per replicate group. Feed and water were provided ad libitum. Vaccines against New Castle disease were administered to the birds immediately after hatching and when they were 28 days old respectively. Gumboro vaccine was administered to the birds when they were 10 and 35 days old respectively. The birds were dewormed adequately, while antibiotics were also given. The average feed intake and the weight gain were determined per week, respectively. The feed conversion efficiency was calculated as the ratio of kilogram body weight gain to kilogram feed intake. The experiment was terminated at the end of the 56 days.

\section{Metabolic Study}

Droppings from each replicate group of birds were collected on four successive days at 24 hours interval during the seventh and eighth week of the experiment in metabolic cages. Two birds with weight close to the average weight of each replicates group was used for this purpose. The droppings collected were weighed fresh, placed in 
aluminum foil, dried to constant weight at $100^{\circ} \mathrm{C}$ for $24 \mathrm{hrs}$ and analyzed for mineral retention using the formula :

Mineral Retention $=[($ Mineral Intake - Mineral in Dropping) / Mineral Intake] x 100

\section{Chemical Analysis}

The proximate composition of the RBS and diet was analysed using the analytical procedure of AOAC (1984). The anti-nutritional factors, tannins oxalate and phytate contents were analyzed using the methods described by Apata (1990).

\section{Statistical Analysis}

All result in this study were subjected to analysis of variance. Where significant, means will be separated using Duncan Multiple Test (Steel and Torrie, 1984).

\section{RESULTS}

The results obtained on the proximate composition (Table 3) showed higher crude protein, ether extract and ash contents in the raw benne seeds. The anti- nutritional factors obtained in the raw benne seeds (Table 4) showed higher phytate than tannin and oxalate contents.

The performance characteristics of broiler chickens (Table 5) showed a high significant $(\mathrm{P}<0.05)$ feed intake in birds fed $15 \%$ RBS supplemented with $0.25 \%$ and $0.5 \%$ lysine. Groups of birds fed 15\% RBS had higher $(\mathrm{P}<0.05)$ feed intake values than those fed $30 \%$ RBS with or without lysine supplementation, respectively. The feed intake was however significantly $(\mathrm{P}<0.05)$ reduced in birds fed $30 \%$ RBS with or without lysine supplementation.

Body weight gain (BWG) was significantly $(\mathrm{P}<0.05)$ increased in birds fed control diet and $15 \%$ RBS supplemented with $0 \%, 0.25 \%$ and $0.5 \%$ lysine, followed in BWG values were birds fed $30 \%$ RBS supplemented with $0 \%, 0.25 \%$ and $0.5 \%$ lysine.

Feed conversion efficiency (FCE) was significantly $(\mathrm{P}<0.05)$ increased in birds fed $15 \%$ RBS supplemented with $0.5 \%$ lysine supplementation. Non-significant difference was obtained between the FCE of birds fed 15\% RBS supplemented with $0 \%$ lysine and those fed 30\% RBS supplemented with $0 \%, 0.25 \%$ and $0.5 \%$ lysine, respectively. Protein efficiency ratio (PER) was similar between birds fed the control diet and $15 \%$ RBS at $0.5 \%$ lysine supplementation, but significantly $(\mathrm{P}<0.05)$ reduced in birds fed $30 \%$ RBS with $0 \%, \quad 0.25 \%$ and $0.5 \%$ lysine supplementation.

Results on mineral retention are shown in Table 6. The calcium and iron retention values obtained in the birds fed 15\% RBS supplemented with $0.5 \%$ lysine were similar with that of the control group, but significantly $(\mathrm{P}<0.05)$ reduced in birds fed diets containing $30 \%$ RBS with $0 \%$, $0.25 \%$ and $0.5 \%$ lysine, respectively. The digestibility of nitrogen and phosphorus retention $(\mathrm{P}<0.05)$ reduced in all groups of birds fed RBS based diets with or without lysine supplementation.

\section{DISCUSSION}

The crude protein and ether extract contents obtained in the raw benne seeds in this study is similar to the findings of Mamputu and Buhr (1991) and Akanji (2002). However, Lutz and Pryztulski (2008) classified benne seed as an incomplete dietary protein source in that it has low amount of lysine. However, unlike most grain legumes, benne seed is rich in methionine. The phytate, oxalate and tannin contents obtained in the raw benne seeds in this study are similar to earlier reports of Akanji (2002).

The higher reductions obtained in the feed intake of the groups of birds fed 30\% RBS - based diets in this study can be attributed in high intake of tannin from the diet. This agrees with the findings of Reddy et al. (2005) who fed tannin rich sorghum grains to growing pullets and reported a reduction in the feed intake at 18 weeks of age. Tannin in some plant seeds has been reported to cause bitter taste which can affect feed intake, especially at higher levels of incorporation in diets of poultry (McRae and Kennedy (2011). Mitjavilli et al. (1977) also reported depression in feed intake in rats fed plants rich in tannin.

The results obtained in the reduction of weight gain in birds fed $30 \%$ RBS with or without lysine supplementation in this study is also much attributed to high intakes of tannin, phytate and oxalate. This observation is consistent with the findings of Mansoori and Acamovic (2006) who reported that free tannins can form complexes with dietary proteins, endogenous proteins and enzymes, thereby reducing growth of monogastric animals. Longstaff and Mcnab (1991) and Ahmed et al. (1991) also reported the effect of tannin on inhibition of lipase and trypsin in broiler chicks fed $150-300 \mathrm{~g} \mathrm{~kg}^{-1}$ of Vicia faba thereby reducing 
Table 1. Percentage Composition of Broiler Starter Diets

\begin{tabular}{lrrrrrrr}
\hline \multicolumn{1}{c}{ Ingredients } & \multicolumn{1}{c}{ T0 } & \multicolumn{1}{c}{ T1 } & \multicolumn{1}{c}{ T2 } & \multicolumn{1}{c}{ T3 } & \multicolumn{1}{c}{ T4 } & \multicolumn{1}{c}{ T5 } \\
\hline Maize & 55.00 & 53.70 & 53.45 & 53.45 & 44.70 & 44.00 & 43.75 \\
Soybean meal & 30.00 & 15.00 & 15.00 & 15.00 & 10.00 & 10.00 & 10.00 \\
Benne seed & - & 15.00 & 15.00 & 15.00 & 30.00 & 30.00 & 30.00 \\
Fish meal & 2.50 & 2.50 & 2.50 & 2.50 & 2.50 & 2.50 & 2.50 \\
Blood Meal & 2.00 & 3.00 & 3.00 & 3.00 & 3.00 & 3.00 & 3.00 \\
Brewer Dried grains & 2.70 & 3.00 & 3.00 & 2.75 & 2.00 & 2.45 & 2.45 \\
Palm oil & 3.00 & 3.00 & 3.00 & 3.00 & 3.00 & 3.00 & 3.00 \\
Bone meal & 2.00 & 2.00 & 2.00 & 2.00 & 2.00 & 2.00 & 2.00 \\
Oyster shell & 1.50 & 1.50 & 1.50 & 1.50 & 1.50 & 1.50 & 1.50 \\
Salt & 0.50 & 0.50 & 0.50 & 0.50 & 0.50 & 0.50 & 0.50 \\
Premix & 0.50 & 0.50 & 0.50 & 0.50 & 0.50 & 0.50 & 0.50 \\
Methionine & 0.30 & 0.30 & 0.30 & 0.30 & 0.30 & 0.30 & 0.30 \\
Lysine & - & - & 0.25 & 0.50 & - & 0.25 & 0.50 \\
Calculated CP (\%) & 22.89 & 22.79 & 22.74 & 22.76 & 22.54 & 22.56 & 22.58 \\
Calculated ME (Kcal/kg) & 3151.41 & 3154.32 & 3152.35 & 3151.73 & 3123.45 & 3122.65 & 3123.24 \\
Calculated lysine (\%) & 1.01 & 0.63 & 0.82 & 0.91 & 0.59 & 0.61 & 0.72 \\
\hline
\end{tabular}

RBS $=$ Raw benne seeds; Lys $=$ Lysine $\quad \mathrm{CP}=$ crude protein $; \mathrm{ME}=$ Metabolizable Energy; $\mathrm{T} 0=$ control; $\mathrm{T} 1$ $=15 \%$ RBS $+0 \%$ Lys; $\mathrm{T} 2=15 \%$ RBS $+0.25 \%$ Lys; $\mathrm{T} 3=15 \%$ RBS $+0.5 \%$ Lys; $\mathrm{T} 4=30 \% \mathrm{RBS}+0 \%$ Lys; T5 $=30 \%$ RBS $+0.25 \%$ Lys; T6 $=30 \%$ RBS $+0.5 \%$ Lys. The 0.50 premix supplied, per kilogram of diet: vitamin A, 12,000 IU; vitamin D3, 2,000 IU; vitamin E, 50 IU; vitamin B1, $1 \mathrm{mg}$; vitamin B2, $3 \mathrm{mg}$; vitamin B6, $1 \mathrm{mg}$; vitamin B12, $10 \mu \mathrm{g}$; vitamin K, $2 \mathrm{mg}$; copper (cupricsulphate), $75 \mathrm{mg}$; nicotinic acid, 12 $\mathrm{mg}$; pantothenic acid, $10 \mathrm{mg}$; iron, $200 \mathrm{mg}$; cobalt, $0.5 \mathrm{mg}$; manganese, $40 \mathrm{mg}$; zinc, $90 \mathrm{mg}$, iodine, $1 \mathrm{mg}$; selenium, $0.2 \mathrm{mg}$; calcium, $31.25 \mathrm{~g}$; sodium, $10 \mathrm{~g}$.

their growth. The high content of phytate in the benne seed used in this study could also have contributed to inhibition of digestibility of protein in the broiler chicks. This is because proteinphytate-cation complex may account for the decrease in mineral bioavailability (Akanji, 2002). The higher values of weight gain in birds fed $15 \%$ RBS based diets could be attributed to lower intakes of tannin, oxalate and phytate, respectively. Moreover, the lysine supplementation at $0.5 \%$ level enhanced the weight gain of birds fed 15\% RBS based diet. This agrees with the reports of Abebe and Morris (1990) that lysine supplementation generally increases growth rate of chicks fed in conjunction with protein levels up to $23 \%$ crude protein. The lysine requirement of a chick was reported to be a linear function of dietary protein content rather than a fixed proportion of the diet provided protein levels ranged between $14 \%$ and $28 \%$.

FCE values of the birds in this study reduced with increasing inclusion level of benne seed, but increased with increasing supplementation level of lysine especially those fed 15\% RBS based diet. This increase in FCE in birds fed 15\% RBS is first attributed to lower intakes of the antinutritional factors. The marked reduction in FCE in birds fed $30 \%$ RBS is similar to the findings of Akanji (2002) who fed broiler chickens with $300 \mathrm{~g} / \mathrm{kgDM}$ of raw benne seeds. Similarly, Essien and Udedibie (2007) reported reduction in FCE of rabbits fed jack beans - based diets containing 
Table 2. Percentage Composition of Broiler Finisher Diets

\begin{tabular}{lrrrrrrr}
\hline Ingredients & \multicolumn{1}{c}{$\mathrm{T} 0$} & \multicolumn{1}{c}{$\mathrm{T} 1$} & \multicolumn{1}{c}{$\mathrm{T} 2$} & \multicolumn{1}{c}{$\mathrm{T} 3$} & $\mathrm{~T} 4$ & \multicolumn{1}{c}{$\mathrm{T} 5$} & \multicolumn{1}{c}{$\mathrm{T} 6$} \\
\hline Maize & 57.00 & 56.00 & 55.75 & 55.50 & 46.00 & 45.75 & 45.50 \\
Soybean meal & 30.00 & 15.00 & 15.00 & 15.00 & 10.00 & 10.00 & 10.00 \\
Benne seed & - & 15.00 & 15.00 & 15.00 & 30.00 & 30.00 & 30.00 \\
Fish meal & 2.50 & 2.50 & 2.50 & 2.50 & 2.50 & 2.50 & 2.50 \\
Blood meal & 1.00 & 1.00 & 1.00 & 1.00 & 1.00 & 1.00 & 1.00 \\
Brewers dried grains & 1.70 & 2.70 & 2.70 & 2.70 & 2.70 & 2.70 & 2.70 \\
Palm oil & 3.00 & 3.00 & 3.00 & 3.00 & 3.00 & 3.00 & 3.00 \\
Bone meal & 2.50 & 2.50 & 2.50 & 2.50 & 2.50 & 2.50 & 2.50 \\
Oyster shell & 1.50 & 1.50 & 1.50 & 1.50 & 1.50 & 1.50 & 1.50 \\
Salt & 0.50 & 0.50 & 0.50 & 0.50 & 0.50 & 0.50 & 0.50 \\
Premix & 0.50 & 0.50 & 0.50 & 0.50 & 0.50 & 0.50 & 0.50 \\
Methionine & 0.30 & 0.30 & 0.30 & 0.30 & 0.30 & 0.30 & 0.30 \\
Lysine & - & - & 0.25 & 0.50 & - & 0.25 & 0.50 \\
Calculated CP (\%) & 20.15 & 20.04 & 20.11 & 20.13 & 20.09 & 20.17 & 20.21 \\
Calculated ME (Kcal/kg). & 3011.11 & 3009.21 & 3009.56 & 3010.11 & 3006.34 & 3006.13 & 3006.42 \\
Calculated lysine (\%) & 1.03 & 0.61 & 0.80 & 0.89 & 0.57 & 0.60 & 0.71
\end{tabular}

Notes in Table 2 are similar to Table 1

Table 3. Proximate Composition of Raw Benne Seeds

\begin{tabular}{lr}
\hline \multicolumn{1}{r}{ Composition } & $\%$ \\
\hline Protein & 25.53 \\
Crude Protein & 4.11 \\
Ether Extract & 51.87 \\
Ash & 5.29 \\
Nitrogen Free Extract & 10.56 \\
Dry Matter & 97.36 \\
\hline
\end{tabular}

Means are for triplicate analysis

toxic factors such as canavanine, haemagglutinin and trypsin inhibitor. Moreover, in the diets of birds fed $15 \%$ RBS, lysine inclusion at $0.5 \%$ gave better FCE than at $0.25 \%$. This increase is similar to the report of D'Mello (2003) that FCE of broiler chicks between 1 to 3 weeks of age
Table 4. Anti-nutritional Factors in Raw Beene Seeds

\begin{tabular}{lc}
\hline \multicolumn{1}{c}{ Anti-nutritional } & Content \\
\hline Tannin, g/100 g DM & 2.47 \\
Phytate, g/ 100 g DM & 4.98 \\
Oxalate, g/ 100 g DM & 2.18 \\
\hline
\end{tabular}

Means are for triplicate analysis

increased curvilinearly with increasing inclusion level of lysine.

The increases in the PER values with increasing inclusion levels of lysine in birds fed $15 \%$ raw benne seeds in this study are in agreement with reports of Baker and Izquiredo (1985) who fed corn-sesame seed meal to broiler chicks. Abebe and Morris (1990) reported that lysine requirement of the chick was a linear function of the dietary protein consumed, and that 
Table 5. Performance Characteristics of Birds Fed Raw Benne Seeds With or Without Lysine

\begin{tabular}{lcccccccc}
\hline & T0 & T1 & T2 & T3 & T4 & T5 & T6 & SEM \\
\hline Feed intake (kg/wk) & $0.517^{\mathrm{a}}$ & $0.493^{\mathrm{b}}$ & $0.502^{\mathrm{ab}}$ & $0.511^{\mathrm{a}}$ & $0.451^{\mathrm{c}}$ & $0.456^{\mathrm{c}}$ & $0.458^{\mathrm{c}}$ & 0.09 \\
Weight gain (kg/wk) & $0.285^{\mathrm{a}}$ & $0.228^{\mathrm{d}}$ & $0.249^{\mathrm{c}}$ & $0.267^{\mathrm{b}}$ & $0.201^{\mathrm{e}}$ & $0.206^{\mathrm{e}}$ & $0.209^{\mathrm{e}}$ & 0.08 \\
FCE & $0.551^{\mathrm{a}}$ & $0.462^{\mathrm{d}}$ & $0.496^{\mathrm{c}}$ & $0.523^{\mathrm{b}}$ & $0.446^{\mathrm{d}}$ & $0.452^{\mathrm{d}}$ & $0.456^{\mathrm{d}}$ & 0.07 \\
PER & $2.454^{\mathrm{a}}$ & $2.213^{\mathrm{c}}$ & $2.325^{\mathrm{b}}$ & $2.445^{\mathrm{a}}$ & $2.073^{\mathrm{d}}$ & $2.084^{\mathrm{d}}$ & $2.087^{\mathrm{d}}$ & 0.13 \\
\hline
\end{tabular}

Notes for T0 to T6 are similar to notes in Table 1. Means along rows with different superscripts are significantly $(\mathrm{P}<0.05)$ different. $\mathrm{RBS}=$ Raw benne seeds; Lys $=$ lysine $; \mathrm{FCE}=$ Feed conversion efficiency; $\mathrm{PER}=$ Protein efficiency ratio; $\mathrm{SEM}=$ Standard error of mean

in diets deficient in lysine, PER increased with increasing inclusion level of the amino, acid. PER was however low in birds fed $30 \%$ RBS with or without lysine supplementation, thus suggesting the overwhelming effects of the toxic compounds on the protein digestibility. Apata (1990) reported the presence of a strong charge between phytic acid and protein, thereby enhancing complex formation which may inhibit enzymatic digestion; and that tannin in particular may exert negative effects on potein digestibility. According to Lutz and Pryztulski (2008), protein-tannin complexes can be resistant to the action of digestive enzymes.

Results on the mineral retention showed that birds fed with diets containing 30\% RBS showed lower values for nitrogen, iron, calcium and phosphorus. This observation can be attributed to decrease of availability of divalent mineral cations such as calcium and Zinc in the birds as a result of the higher intake of phytate and oxalate in the raw benne seeds. Lutz and Pryztulski (2008) reported that the main nutritional concern associated with phytate lies in its interaction with metal ions such as calcium, magnesium, zinc, copper and iron to form insoluble phytate mineral complexes that are not readily broken down, thus rendering them unavailable or only partially available for absorption in the intestinal tract of an animal. Akanji (2002) reported significant negative correlations between nitrogen retention and either of oxalate or phytate intakes of broiler birds fed raw and bambara groundnuts.

\section{CONCLUSION}

From the results obtained in this study, birds fed $15 \%$ RBS with or without lysine supplementation performed better than those fed $30 \%$ RBS as a result of lower intakes of tannin, oxalate and phytate. Second, in birds fed $15 \%$ RBS, lysine supplementation at $0.5 \%$ significantly $(\mathrm{P}<0.05)$ increased the response indices. Long time feeding of diets containing above 15\% RBS may have the tendency to constitute much danger to the health of the birds. Moreover, proper processing of the RBS may improve the nutritive quality when incorporated at higher levels in broiler diets, provided there is sufficient lysine supplementation.

\section{REFERENCES}

Abebe, S. and T.R., Morris 1990 . Note on the effects of protein concentration on responses of responses of dietary lysine by chicks. Br. Poult. Sci. 31:255-260

Ahmed A.E., R., Smithar and M. Ellis 1991. Activities of enzymes of the enzymes of the pancreas and the lumen and mucosa of the small intestine in growing broiler cockerels fed tannin containing diets. Br. J. Nutr. 65:189-197.

Akanji, A.M. 2002. Enhancing The Utilization of Some Tropical Legume Seeds in Diets of Exotic Chickens. PhD Thesis. University of Ibadan.

AOAC. 1984. Official methods of analysis $\left(14^{\text {th }}\right.$ ed.). Association of Official Analytical Chemists, Washington, D. C.

Apata, D.F. 1990. Biochemical, Nutrition and Toxicological Assessment of Some Tropical Legume Seeds. PhD Thesis, University of Ibadan.

Baker, D.H. and O.A. Izquierdo. 1985. Effect of meal frequency and spaced crystalline 
lysine ingestion on the utilization of dietary lysine by chickens. Nutr. Res. 5:1103-1112

Blood, A.E and J.A. Henderson. 1974. Veterinary Medicine. $4^{\text {th }}$ edition, Bailere, Tindall. Pp820-821

D'Mello, J.P.F. 2003 Response of Growing Poultry to Amino Acids. $2^{\text {nd }}$ ed. $C A B$ Int. Pub. pp 237-241

Emiola I.A., A.D. Ologhobo, T.A. Adedeji, I.O. Oladunjoye and A.M. Akanji 2003. Performance characteristic of broiler chicks fed kidney beans as replacement for two conventional legumes. Moor J. Agric. Res. 4:236-241

Essien, C.A. and A.B.I. Udedibie. 2007. Effect of two-stage cooking on haemagglutinin and anti-tryptic activity of jack bean and its nutrition value for young growing rabbit. Proc. $32^{\text {nd }}$ Conference of Nigerian Society for Anim. Prod. .

Longstaff, M.A. and J.B. Mcnab. 1991. The effect of concentration of tannin rich bean hulls (Vicia faba L.) on activities of lipase (EC. 3.1.3.) and alpha amylase (E.C.3.2.1.1) in digesta and pancreas on the digestion of lipid and starch by young chicks. Br. J. Nutr. 66:139-147.

Lutz, C. and K. Pryztulski. 2008. Nutrition and Diet Therapy. $4^{\text {th }}$ Ed Jaypee Brothers Medical Publishers. New Delhi.

Maga, J.A. 1982. Phytate: Its chemistry, occurrence, food interactions, nutritional significance and methods of analysis. J. Agric. Food Chem. 30:1-9

Mamputu, M. and R.J. Buhr. 1991. Effects of substituting sesame meal for soybean on layer performance. Poult. Sci. 70 (suppl 1):77.

Mansoori, B. and T. Acamovic. 2006. The effect of tannic acid on the excretion of endogenous methionine, histidine and lysine with broilers. Anim. Feed Sci. Technol. 134 (3-4):198-210.

McRae J.M and J.A. Kennedy. 2011. Wine and grape tannin interactions with salivary proteins and their impact on astringency: a review of current research. Molecules. 16(3): 2348-64

Mitjavila, S., C. Lacombe, G. Carrera and R. Derache. 1997. Tannic acid and oxidized tannic acid on the functional state of rat intestinal epithelium. J. Nutr. 109:255-285.

Ologhobo, A.D., D.E. Apata and A. Oyejide. 1993. Utilization of raw jack bean (Canavaliaensiformis) and jack bean fraction in diets for broiler chicks. Br. Poult. Sci. 34:323-337

Permaul, P. 2009. Sesame allergy role of specific $\operatorname{IgE}$ and skin-prick testing predicting food challenge results. Allergy and Asthma Proc. 30(6):643-48

Reddy, R.A., R.V. Reddy, P.P. Rao, K.G. Reddy, V.S. Reddy and C.H.N. Rao. 2005. Performance of layers on sorghum based poultry feed rations. Sat e-journal. 1(1):1-4.

Rezaei, M, H.M. Nassiri, R.J. Pour and H. Kermanshahi. 2004. The effects of dietary protein and lysine levels on broiler performance, carcass characteristics and $\mathrm{N}$ excretion. Int. J. Poult. Sci. 3(2):148-152 